\title{
FAKTOR KEGAGALAN PERSEPSI PADA PEMBENTUKAN CITRA PARTISIPAN DALAM DEBAT POLITIK DI TELEVISI
}

\author{
Winny Gunarti Widya Wardani \\ Program Studi Desain Komunikasi Visual \\ Fakultas Bahasa dan Seni, Universitas Indraprasta PGRI, Jakarta. \\ winny.gunartiww@unindra.ac.id
}

\begin{abstract}
Abstrak
Debat politik melalui media televisi berpotensi membangun citra partisipan. Oleh karena itu, program debat politik melalui televisi umumnya didesain untuk membentuk persepsi visual penonton yang sesuai dengan tujuan yang ingin dicapai. Tampilan di layar televisi memiliki kekuatan visual karena dapat berkomunikasi melalui bahasa visual nonverbal berupa teks dan gambar. Proses pembentukan citra partisipan melalui persepsi penonton tidak terlepas dari nilai-nilai budaya masyarakat. Dalam hal ini, ada lima faktor utama yang berpotensi mempengaruhi kegagalan persepsi terhadap pembentukan citra, yaitu kesalahan atribusi, efek halo, stereotip, prasangka, dan gegar budaya. Studi ini membahas secara deskriptif kualitatif kelima faktor tersebut dengan pendekatan semiotika visual, berupa pembacaan tanda-tanda visual melalui pesan kinesik yang bersifat ikonik, indeksikal, dan simbolis. Hasil pembahasan studi ini diharapkan dapat menjadi referensi ilmiah tentang faktor kegagalan persepsi dan pembentukan citra partisipan melalui layar televisi.
\end{abstract}

Kata kunci : kegagalan persepsi, citra partisipan, televisi

\section{FAILURE FACTORS OF PERCEPTION IN THE FORMATION OF PARTICIPANT IMAGE IN POLITICAL DEBATE ON TELEVISION}

\begin{abstract}
Political debate through the medium of television has the potential to build the image of the participants. Therefore, the political debate through television programs are generally designed to form a visual perception of the audience that in accordance with the objectives to be achieved. The display on the television screen has the visual power to communicate through nonverbal visual language in which the text and especially images. The process of image formation of participants through the audience's perception is inseparable from the cultural values of society. In this case, there are five main factors that could potentially affect the failure of the perception of image formation, namely attribution error, the hello effect, stereotypes, prejudice, and cultural shock. Qualitatively, this study discusses that five factors with visual semiotics approach and in the form of visual reading of the signs of kinesik messages that are iconic, indexical, and symbolic. The results of this study are expected to be a scientific reference about the failure factors of perception and the formation of image participants through the television screen.
\end{abstract}

Keywords : failure of perception, participant image, television 


\section{PENDAHULUAN}

Acara debat politik melalui televisi adalah salah satu alat propaganda yang sering dipakai untuk membentuk citra partisipan dari partai politik tertentu dalam upaya membentuk persepsi visual penontonnya. Bentuk acara debat politik umumnya didesain dalam bentuk talkshow di studio dengan kehadiran penonton atau tanpa penonton. Debat politik dapat dianggap sebagai bagian dari iklan politik. Sebagaimana dikatakan Danesi (2011:295), iklan yang bersifat sosial politik yang ditayangkan melalui media massa dapat dimanfaatkan untuk mengiklankan pandangan-pandangan mereka.

Dalam konteks desain komunikasi visual, debat politik melalui televisi berkomunikasi melalui sistem signifikasi yang dibangun terutama melalui bahasa visual teks dan gambar. Keduanya dapat merepresentasikan pesan-pesan yang disesuaikan dengan tujuan politik maupun kebutuhan penontonnya. Pembacaan dan pemaknaan terhadap bahasa visual melalui layar televisi dapat membentuk persepsi sosial penontonnya. Persepsi sosial menurut Mulyana (2013, 191-207) dapat didasarkan pada persepsi berdasarkan pengalaman, bersifat selektif, bersifat dugaan, bersifat evaluatif, dan bersifat kontekstual. Oleh karena itu, persepsi visual penonton terhadap sebuah tayangan debat politik dapat beragam, terutama persepsi mereka terhadap citra partisipan sebagai subjek politik.

Dengan demikian televisi dapat menjadi alat perubahan sosial. Dalam konteks debat politik, visualisasi partisipan sebagai wakil partai politik melalui layar dapat menimbulkan berbagai konotasi. Umumnya desain debat politik di televisi telah disesuaikan dengan nilai-nilai sosial budaya yang berlaku di masyarakat. Ketika nilai-nilai sosial budaya ini dapat memenuhi dan memuaskan kebutuhan penonton, maka pesan-pesan kampanye dapat menjadi konvensi di masyarakat. Itulah sebabnya, janji-janji politik sebagai pesan-pesan yang dikodekan melalui layar televisi kerap dikonstruksi untuk menarik perhatian masyarakat.

Hal ini sesuai dengan yang dikatakan Fiske (2007:203), bahwa konvensi melalui televisi dapat berbeda dari konvensi dunia nyata, dan perbedaan tersebut menghasilkan kode yang berbeda pula. Itulah yang disebut sebagai kode konotasi yang berasal dari bentuk penanda yang dihasilkan melalui teknikteknik pengambilan gambar, yang memungkinkan persepsi orang berbedabeda. Dikatakan Mulyana (2013:230), persepsi orang sering tidak cermat karena adanya asumsi atau pengharapan yang berbeda. Hal inilah yang menyebabkan terjadinya kekeliruan atau kegagalan persepsi.

Hal ini sesuai dengan pemikiran Fiske (dalam Hamad, 2010:15), bahwa yang dikirimkan dalam komunikasi bukan semata-mata pesan, tetapi yang lebih esensial adalah menanamkan makna tertentu atau generating of meaning ke dalam pikiran penerima. Pikiran bawah sadar inilah yang dipengaruhi untuk membentuk persepsi visual. Persoalannya adalah, persepsi yang diharapkan kadang tidak sesuai, sehingga sasaran yang dituju tidak tercapai. Hal ini bisa terjadi karena dipengaruhi faktor manusianya saat memaknai pesan, yang tidak dapat melepaskan dirinya dari ketergantungan dan keterikatannya pada sistem nilai budaya yang dianut.

\section{PEMBAHASAN}

Secara kualitatif, studi ini membahas faktor-faktor kegagalan persepsi dengan pendekatan semiotika visual, yaitu studi tentang tanda visual. 
Menurut Danesi (2011:75), studi tanda visual dapat didefinisikan secara sederhana sebagai tanda yang dikonstruksi dengan sebuah penanda visual, yaitu penanda yang dapat dilihat oleh indera penglihatan. Tanda-tanda visual ini dapat dibentuk secara ikonis (yaitu tanda pada gambar yang mewakili ciri-ciri dan menyerupai objek tertentu), indeksikal (yaitu tanda pada gambar yang menunjukkan adanya suatu fenomena, peristiwa, atau adanya hubungan sebabakibat), dan simbolis (yaitu tanda yang telah diketahui umum karena telah menjadi sebuah konvensi di masyarakat).

Ketika seorang partisipan dihadirkan secara visual melalui layar televisi sebagai bagian dari acara debat politik, maka secara tidak langsung kehadirannya mendorong penontonnya untuk memberikan makna terhadap stimuli melalui layar, yaitu persepsi. Desiderato (1976, dalam Rakhmat, 2008:51) mengatakan, menafsirkan makna informasi secara inderawi tidak hanya melibatkan sensasi, tetapi juga atensi, ekspektasi, motivasi, dan memori (Rakhmat, 2008:51). Adanya perbedaan dari atensi, ekspektasi, motivasi dan memori pada penonton inilah yang memungkinkan timbulnya kegagalan persepsi terhadap citra partisipan.

\section{Faktor Kegagalan Persepsi}

Secara teoritis, ada lima faktor yang mempengaruhi kegagalan persepsi, yaitu (Mulyana, 2013:230-251):

Kesalahan atribusi

Atribusi adalah proses internal di dalam diri manusia untuk memahami penyebab perilaku orang lain. Kesalahan terjadi ketika perilaku orang dijadikan sumber informasi mengenai sifat-sifat mereka. Pesan yang dipersepsi tidak utuh atau tidak lengkap, sehingga manusia berusaha menafsirkan sendiri kekurangan pesan atau rangsangan inderawi yang didapat

Efek Halo

Efek halo merujuk pada fakta bahwa begitu manusia membentuk kesan menyeluruh tentang seseorang, maka cenderung menimbulkan efek yang kuat atas penilaian terhadap sifat-sifat spesifiknya. Kesan pertama menjadi kesan menyeluruh dan berefek kuat atau sulit digoyahkan, sehingga dapat menjadi hukum keprimaan (law of primacy). Kesan pertama menjadi penting untuk menimbulkan efek halo. Efek halo bisa ditimbulkan melalui ciri-ciri fisik atau perilaku. Jika kesan pertama positif, maka kecenderungan selanjutnya adalah positif. Demikian pula sebaliknya.

\section{Stereotip}

Stereotip adalah kategorisasi atas suatu kelompok secara serampangan dengan mengabaikan perbedaanperbedaan individual. Kelompokkelompok ini mencakup: kelompok ras, kelompok etnik, kaum tua, berbagai pekerjaan dan profesi, gender, atau orang dengan penampilan fisik tertentu.

\section{Prasangka}

Prasangka adalah konsekuensi dari stereotip, dan lebih teramati dari stereotip. Prasangka adalah sikap yang tidak adil terhadap seseorang atau kelompok. Suatu penilaian berdasarkan keputusan dan pengalaman terdahulu. Prasangka umumnya bersifat negatif. Wujud prasangka yang nyata dan ekstrem adalah diskriminasi. Prasangka bersifat alamiah dan tak terhindarkan. Budaya dan kepribadian memengaruhi prasangka.

Gegar Budaya

Gegar budaya adalah benturan persepsi yang diakibatkan penggunaan persepsi berdasarkan nilai-nilai budaya yang dipelajarinya di lingkungan yang 
baru, yang nilai-nilai budayanya berbeda dan belum dipahami. Benturan persepsi itu menimbulkan konflik dan dapat menyebabkan tekanan di dalam diri.

Dalam bahasa visual di layar televisi, kelima faktor di atas dapat persepsikan melalui klasifikasi pesan nonverbal, yang disebut Dale G. Leathers (dalam Rakhmat (2008:289-292) sebagai presentasi pesan kinesik, yaitu pesan yang disampaikan melalui bahasa tubuh, seperti ekspresi wajah dan tampilan tubuh. Selain itu, ada pula pesan artifaktual yang menyertainya, yang diungkapkan melalui pakaian, kosmetik, atau aksesori. Penelitian yang dilakukan Gunarti W.W., Piliang, dan Syarief (2013:375), menerjemahkan bahasa tubuh dalam tanda fasial berupa ekspresi wajah, orientasi wajah, dan arah tatapan. Sedangkan bahasa tubuh dalam tanda postural meliputi gerakan tangan, perilaku khas, dan posisi tubuh.

Acara debat politik di televisi sebagai alat propaganda memiliki kekuatan visual untuk membentuk citra partisipan, baik yang disesuaikan atau tidak sesuai dengan harapan masyarakat. Selama tayangan berlangsung, yang umumnya dikedepankan adalah citra partisipan yang ideal, yaitu substansi seorang pemimpin yang nasionalis. Secara visual, hal ini bisa dipresentasikan menjadi partisipan yang pandai mengungkapkan pikirannya, mempunyai rencana yang jelas, dan mampu menunjukkan hasil-hasil yang telah dicapai. Apabila hal yang dipresentasikan dianggap tidak sesuai dengan harapan masyarakat, maka potensi kegagalan persepsi penonton dapat terjadi. Faktorfaktor yang mempengaruhi kegagalan persepsi tersebut dapat dibahas menurut presentasi tanda visual ikonik, tanda visual indeksikal, dan tanda visual simbolis.

\section{Presentasi Tanda Visual Ikonik, Indeksikal, dan Simbolis}

Dalam presentasi tanda visual ikonik, diketahui bahwa penonton dapat membangun persepsinya melalui pembacaan tanda berdasarkan ciri-ciri khusus yang mewakili. Tanda-tanda ikonik dapat dibaca sebagai pesan kinesik. Artinya, penonton dapat memberikan persepsinya berdasarkan tanda-tanda fasial dan posturalnya, yaitu bentuk wajah, raut wajah, bentuk tubuh, dan proporsi tubuh.

Ketika proses internal di dalam diri penonton berinteraksi untuk memberikan penilaian berdasarkan asumsi atas karakteristik fisik yang ditampilkan, maka pesan sebagai rangsangan inderawi yang diterimanya dapat menjadi tidak utuh dan memungkinkan timbulnya kesalahan atribusi. Hal ini dapat terjadi ketika penonton misalnya memiliki kriteria khusus terhadap karakteristik fisik calon pemimpin, apakah ia harus berwajah dan bertubuh ideal serta menarik. Terlihat ideal dalam kamus didefinisikan sebagai hal yang sangat sesuai dengan apa yang diinginkan. Persoalannya adalah, apa yang dianggap seseorang ideal belum tentu ideal bagi orang lain. Ini sama halnya dengan cara penonton mempersepsikan seorang pembawa acara perempuan di televisi yang harus selalu ditampilkan menarik.

Hal lain dalam kesalahan atribusi yang juga dapat terjadi adalah ketika penonton tidak sepenuhnya menyaksikan acara tersebut, sehingga tidak menerima pesan di awal berupa konten perkenalan tentang partisipan. Ketidakutuhan pesan yang diterimanya mengakibatkan referensi penonton tentang karakter partisipan menjadi tidak lengkap dan menimbulkan persepsi yang tidak sesuai harapan.

Dengan demikian, fungsi penggunaan bahasa visual menjadi 
penting karena tidak semata menyajikan ekspresi wajah atau tampilan tubuh, melainkan kemampuan untuk menyampaikan pesan melalui visualisasi yang asosiatif dan imajinatif. Umumnya, upaya-upaya untuk menarik perhatian penonton diaplikasikan melalui tampilan fasial dan postural subjek. Akan tetapi, sebagai penonton yang membaca pesan, menurut Frascara (2004:58), cara kita melihat bukanlah tindakan yang bersifat pasif. Kita tidak memperhatikan untuk melihat, kita memperhatikan untuk memahami, dan untuk menemukan apa yang kita inginkan. Signifikasi dan relevansi adalah tujuan utama yang dapat menarik perhatian. Itulah yang membentuk persepsi dan makna.

Oleh karena itu, faktor kesalahan atribusi menuntut perencanaan citra partisipan yang sesuai dengan harapan masyarakat. Televisi memang memiliki kekuatan untuk menyampaikan informasi, edukasi, sekaligus hiburan. Akan tetapi, dalam konteks acara debat politik, citra partisipan sebagai subjek dan objek politik tidak hanya dilihat sebatas pesan informasinya, melainkan juga dipengaruhi bagaimana ia menyampaikan pesan tersebut melalui tampilannya secara keseluruhan. Dalam penelitiannya tentang televisi dan imajinasi, Singer dan Singer (2005:82) mengatakan bahwa hal yang dapat membangun imajinasi adalah konten dan mereka yang sungguh-sungguh peduli untuk menontonnya.

Selanjutnya, dalam presentasi tanda visual indeksikal, diketahui bahwa persepsi penonton dapat terbentuk berdasarkan pengalaman dan pengetahuannya tentang tokoh politik tersebut. Ini artinya hal-hal yang dipersepsikan terkait dengan peristiwa sebelumnya yang memiliki hubungan sebab akibat. Di dalam tanda indeksikal, kegagalan persepsi dipengaruhi faktor efek halo, stereotipe, dan prasangka.
Kegagalan persepsi karena efek halo dapat terjadi, ketika penonton pernah memiliki pengalaman dan pengetahuan tentang partisipan, baik itu peristiwa yang dialami sendiri, atau yang dibaca melalui media. Ketika kesan pengalaman dan pengetahuan penonton cenderung bersifat negatif, maka penilaian selanjutnya terhadap sifat-sifat spesifik partisipan menjadi cenderung negatif pula. Demikian pula kegagalan persepsi karena faktor stereotip. Presentasi tanda visual dapat dibaca dan dimaknai sebagai tanda yang bersifat indeksikal karena adanya fenomena tentang kelompok-kelompok atau individu-individu tertentu yang melekat di pikiran penonton, seperti persepsinya terhadap suku bangsa tertentu. Faktor stereotip ini biasanya diikuti oleh faktor prasangka, sebagai bagian dari konsekuensinya. Misalnya, latar belakang partisipan yang berasal dari suku bangsa tertentu dianggap memiliki karakter-karakter yang tidak sesuai dengan suku bangsa tempat masyarakat penonton itu berada.

Kecenderungan faktor stereotip dan prasangka yang negatif dengan sendirinya menghasilkan persepsi yang negatif. Dalam hal ini, presentasi fasial dan posturalnya bisa dilihat dari ekspresi wajahnya, caranya berbicara, dan caranya menatap penonton. Gaya gerakan tubuhnya secara keseluruhan juga bisa mencerminkan stereotip yang tidak sesuai dengan harapan penonton.

Kemudian presentasi tanda visual secara simbolis terhadap potensi munculnya kegagalan persepsi dapat terjadi karena adanya faktor gegar budaya. Penonton televisi bersifat heterogen, berasal dari berbagai suku bangsa dan latar belakang budaya. Lokasi tempat tinggal penonton otomatis mempengaruhi pula cara mereka berpikir dan memaknai pesan. Tidak semua penonton dapat menerima nilai-nilai budaya yang dianut oleh partisipan. 
Apalagi jika partisipan menawarkan perubahan nilai-nilai budaya sebagai janji-janji politik yang membawa perbaikan.

Kegagalan persepsi dapat terjadi ketika penonton tidak menemukan simbol-simbol hubungan sosial yang dikenalnya melalui apa yang ditampilkan layar televisi, sehingga penonton merasa tidak memiliki keterkaitan dengan partisipan. Tindakan yang dapat terjadi adalah penonton menolak untuk menonton dan menghindari acaranya. Ketidakinginan penonton untuk terlibat dengan aktivitas politik partisipan dapat dikelompokkan pada faktor gegar budaya. Artinya ia menolak untuk beradaptasi dengan nilai-nilai budaya yang dianut oleh partisipan, atau ia memang secara sadar menolak perbedaan dan perubahan nilai-nilai budaya yang ditawarkan partisipan. Sikap penolakan terhadap nilai-nilai budaya yang tidak dikenalnya tersebut cenderung membentuk persepsi yang keliru tentang suatu hal.

Akan tetapi, ada pula orang-orang yang dapat mudah menyesuaikan diri Tabel 1. Presentasi Tanda Visual yang Mempengaruhi Kegagalan Persepsi

\begin{tabular}{|l|l|l|l|l|}
\hline \multicolumn{2}{|c|}{ Tabel 1. Presentasi Tanda Visual yang Mempengaruhi Kegagalan Persepsi } \\
\hline No & Tanda Visual & Presentasi Tanda & Faktor & Kegagalan Persepsi \\
\hline 1 & Ikonik & $\begin{array}{l}\text { Bentuk wajah } \\
\text { Bentuk tubuh } \\
\text { Proporsi tubuh }\end{array}$ & $\begin{array}{l}\text { Kesalahan } \\
\text { atribusi }\end{array}$ & $\begin{array}{l}\text { Bentuk wajah, bentuk } \\
\text { tubuh dan proporsi tubuh } \\
\text { tidak sesuai dengan } \\
\text { harapan, karena adanya } \\
\text { kriteria tertentu terkait } \\
\text { pengalaman dan } \\
\text { pengetahuan tentang } \\
\text { nilai-nilai sosial budaya, } \\
\text { serta dan tidak } \\
\text { lengkapnya informasi } \\
\text { yang didapat. }\end{array}$ \\
\hline 2 & Indeksikal & $\begin{array}{l}\text { Ekspresi wajah } \\
\text { Cara menatap } \\
\text { Cara berbicara }\end{array}$ & $\begin{array}{l}\text { Efek halo } \\
\text { Stereotip } \\
\text { Prasangka }\end{array}$ & $\begin{array}{l}\text { Ekspresi wajah, cara } \\
\text { menatap, dan cara } \\
\text { berbicara tidak sesuai } \\
\text { dengan harapan, karena } \\
\text { adanya pengetahuan yang } \\
\text { didasarkan pada sifat-sifat } \\
\text { dan karakteristik }\end{array}$ \\
\end{tabular}

dengan lingkungannya, namun tetapi ketika ia melihat tayangan di televisi yang tidak sesuai dengan latar belakang sosial budayanya sejak kecil, maka ia dapat juga mengalami kegagalan persepsi. Ini disebabkan ketika seseorang itu melakukan interaksi komunikasi, maka menggunakan sejumlah asumsi dan alatalat budaya sebagaimana budaya itu sendiri diekspresikan oleh komunikasi (Barker, 2014:45). Akibatnya, ketika pesan disampaikan melalui pengorganisasian tanda-tanda visual, maka makna yang dihasilkan dapat bersifat majemuk. Presentasi tanda visual simbolis yang dapat mempengaruhi kegagalan persepsi juga dapat dibaca melalui pesan kinesik dan artifaktual. Misalnya, partisipan menampilkan tandatanda simbol melalui gaya berpakaian dan gaya aksesori yang tidak sesuai dengan konvensi di masyarakat.

Secara garis besar, presentasi dan pembacaan tanda visual dalam kegagalan persepsi dapat dilihat pada tabel berikut: 


\begin{tabular}{|l|l|l|l|}
\hline & & & $\begin{array}{l}\text { kelompok atau komunitas } \\
\text { tertentu secara umum, } \\
\text { sehingga penilaian } \\
\text { terhadap partisipan } \\
\text { sebagai individu menjadi } \\
\text { terabaikan }\end{array}$ \\
\hline 3 & Simbolis & $\begin{array}{l}\text { Gaya berpakaian } \\
\text { Gaya aksesori }\end{array}$ & Gegar budaya \\
& $\begin{array}{l}\text { Gaya berpakaian dan } \\
\text { gaya aksesori tidak sesuai } \\
\text { dengan harapan, karena } \\
\text { tidak ditemukannya } \\
\text { simbol-simbol hubungan } \\
\text { sosial yang dikenalnya } \\
\text { melalui apa yang } \\
\text { ditampilkan, sehingga } \\
\text { penonton merasa tidak } \\
\text { memiliki keterkaitan } \\
\text { dengan partisipan dan } \\
\text { menolak untuk terlibat } \\
\text { atau beradaptasi dengan } \\
\text { perubahan nilai-nilai } \\
\text { budaya yang ditawarkan. }\end{array}$ \\
\hline
\end{tabular}

Demikian hasil pembahasan tentang faktor-faktor yang mempengaruhi kegagalan persepsi dalam membaca tanda-tanda visual pada presentasi debat politik di televisi.

\section{PENUTUP}

Debat politik di televisi perlu didesain berdasarkan kebutuhan penontonnya, agar persepsi visual terhadap citra partisipan yang diharapkan dapat terbentuk. Faktor kegagalan persepsi dapat terjadi karena adanya ketidaksesuaian dengan harapan penonton. Selain itu, proses penyampaian dan penerimaan pesan juga tidak terlepas dari nilai-nilai budaya masyarakat.

Pembacaan tanda visual melalui presentasi tanda kinesik dapat dimaknai dengan persepsi yang berbeda oleh penonton, sehingga menjadi faktor yang mempengaruhi kegagalan persepsi. Secara ikonik, persepsi terhadap tandatanda visual yang dipresentasikan melalui bentuk wajah, bentuk tubuh, dan proporsi tubuh, dapat dipengaruhi kesalahan atribusi, yaitu perbedaan dalam menetapkan kriteria tertentu dalam diri seseorang berdasarkan pengalaman dan pengetahuan nilai-nilai budaya yang pernah dipelajarinya. Secara indeksikal, persepsi visual terhadap tanda-tanda visual yang dipresentasikan melalui ekspresi wajah, cara berbicara dan cara menatap penonton, dapat dipengaruhi efek halo, stereotipe, dan prasangka, yaitu persepsi yang hanya didasarkan pada kesan pertama dan karakteristik kelompok, dengan mengabaikan sifat individu. Sedangkan secara simbolis, persepsi terhadap gaya berpakaian dan gaya aksesori dapat dipengaruhi faktor gegar budaya yang dirasakan seseorang, karena kehilangan simbol-simbol yang pernah dikenalnya. Akhirnya, sebagai saran, studi ini dapat menjadi referensi ilmiah dalam merencanakan tayangan televisi yang bertujuan membentuk citra partisipan melalui bahasa visual teks dan gambar. 


\section{DAFTAR PUSTAKA}

Barker, C. (2014). Kamus Kajian Budaya. Yogyakarta: Penerbit Kanisius.

Danesi, M. (2011). Pesan, Tanda, Makna, Buku Teks Dasar Mengenai Semiotika dan Teori Komunikasi. Yogyakarta: Jalasutra.

Fiske, J. (2007). Cultural and Communication Studies. Sebuah Pengantar Paling Komprehensif. Cetakan ke-4. Yogyakarta: Jalasutra.

Frascara, J. (2004). Communication Design, Principles, Methods, and Practice. New York: Allworth Press.

Hamad, I. (2010). Komunikasi Sebagai Wacana. Jakarta: La Tofi Enterprise.
Mulyana, D. (2013). Ilmu Komunikasi, Suatu Pengantar. Cetakan ke-17. Bandung: PT. Remaja Rosdakarya.

Rakhmat, J. (2008). Psikologi Komunikasi. Cetakan ke-26. Bandung: PT. Remaja Rosdakarya.

Singer, D. G. dan Singer, J. L. (2005). Imagination and Play In The Electronic Age. Harvard University Press.

Wardani, W. G. W., Piliang, Y. A. dan Syarief, A. (2013). Wacana Visual Talk Show 'Mata Najwa': Melihat Bahasa Tubuh Partisipan Sebagai Kekuatan Visual. Jurnal Panggung, Vol. 23 No.4, Desember 2013, hal. 375. Bandung: Institut Seni Budaya Indonesia (ISBI). Dapat diakses melalui https://jurnal.isbi.ac.id/index.php/ panggung/article/view/149 